Original Research Paper

\title{
Inovasi Teknologi Pengolahan Limbah Sabut Kelapa di Desa Sigar Penjalin
}

\author{
Bulkaini $^{*}$, Dwi Anggara Ristami ${ }^{2}$, Noviani Adhiningsih ${ }^{3}$, Dian Maulana ${ }^{4}$ \\ ${ }^{1}$ Fakultas Peternakan Universitas Mataram \\ ${ }^{2}$ Program Studi Akuntansi Fakultas Ekonomi dan Bisnis Universitas Mataram \\ ${ }^{3}$ Program Studi Agribisnis Fakultas Pertanian Universitas Mataram \\ ${ }^{4}$ Program Studi Ilmu Hukum Fakultas Hukum Universitas Mataram
}

https://doi.org/10.29303/jpmpi.v3i2.968

Sitasi: Bulkaini., Ristami, D. A., Adhiningsih, N \& Maulana, D (2021). Inovasi Teknologi Pengolahan Limbah Sabut Kelapa di Desa Sigar Penjalin. Jurnal Pengabdian Magister Pendidikan IPA, 4(3)

Article history

Received: 31 Agustus 2021

Revised: 18 September 2021

Accepted: 19 September 2021

*Corresponding Author:

Bulkaini, Fakultas

Peternakan Universitas

Mataram, Mataram,

Indonesia.

Email: b_kaini@yahoo.com

\begin{abstract}
Desa Sigar Penjalin Kecamatan Tanjung, merupakan salah satu desa penghasil kelapa di Kabupaten Lombok Utara. Sebelum dijual ke konsumen, kelapa yang dihasilkan dikupas terlebih dahulu sehingga menghasilkan limbah yang disebut sabut kelapa. Sampai saat ini limbah sabut kelapa belum secara maksimal dimanfaatkan oleh masyarakat, sehingga menimbulkan masalah baru yaitu terjadinya pencemaran lingkungan. Hal ini disebabkan karena kurangnya kesadaran dan motivasi masyarakat untuk mengolah limbah serabut kelapa menjadi sesuatu yang bernilai ekonomis. Salah satu solusi yang dapat dilakukan untuk mengatasi permasalahan tersebut adalah pengadaan penyuluhan dan pelatihan pemanfaatan limbah sabut kelapa menjadi barang yang bernilai ekonomis seperti dibuat menjadi pot bunga, dan kotak tempat pensil. Tujuan dari program ini adalah memberdayakan masyarakat Desa Sigar Penjalin dalam memanfaatkan limbah sabut kelapa menjadi barang yang bernilai ekonomis. Metode yang digunakan dalam melaksanakan program adalah metode Participatory Research Appraisal (PRA) yaitu bentuk metode yang melibatkan semua anggota mitra sasaran dalam melakukan melakukan program kerja. Dari program yang telah dilaksanakan, diperoleh hasil bahwa sekitar $75 \%$ anggota kelompok ibu-ibu PKK Desa Sigar Penjalin siap untuk mengolah limbah sabut kelapa menjadi barang yang bernilai ekonomis. Hasil monitoring dan evaluasi menunjukkan bahwa pengolahan limbah sabut kelapa menjadi barang yang bernilai ekonomis secara tidak langsung dapat meningkatkan pendapatan ibu-ibu PKK.
\end{abstract}

Keywords: Lingkungan, Nilai ekonomis, Sabut kelapa

\section{Pendahuluan}

Desa Sigar Penjalin merupakan salah satu desa yang berada di Kecamatan Tanjung, Kabupaten Lombok Utara, Provinsi Nusa Tenggara Barat dengan luas 14,29 Km2 (Badan Pusat Statistik, 2021). Masyarakat di Desa Sigar Penjalin memiliki mata pencaharian yang cukup beragam. Mata pencaharian yang paling dominan berada di sektor pertanian. Hasil perkebunan seperti Mente dan kelapa menjadi komoditi yang telah mendongkrak pendapatan dan meningkatkan kesejah-traan masyarakat.

Kelapa tergolong dalam marga Cocos dari suku aren-arenan. Semua bagian dari tumbuhan ini dapat dimanfaatkan sehingga dikatakan sebagai tanaman serbaguna, terutama bagi masyarakat pesisir (Azzaki dan Dawud, 2020). Selanjutnya dikatakan bahwa dari bagian daun, bunga, buah, 
batang, dan bagian akar dapat memberikan manfaat bagi lingkungannya dan manusia. Kelapa terdiri dari kulit luar, sabut kelapa, tempurung, kulit daging buah, daging buah, dan air kelapa.

Pengolahan buah kelapa umumnya masih terfokus pada pengolahan hasil daging buah sebagai hasil utama, sedang-kan pengolahan bagian lain dari buah kelapa masih sangat kurang (Amin et al., 2014). Umumnya masyarakat mengolah limbah sabut kelapa sebagai bahan bakar. Tidak jarang sabut kelapa tersebut menjadi limbah yang dibiarkan saja. Meskipun tergolong dalam jenis limbah organik, jika dibiarkan akan mengakibatkan dampak lingkungan seperti penumpukan sampah seiring meningkatnya produksi kelapa. Apabila masyarakat Desa Sigar Penjalin lebih peka terhadap lingkungan, sabut kelapa memiliki nilai ekonomis yang cukup baik.

Dengan banyaknya limbah sabut kelapa yang bertambah setiap harinya, maka kita dapat membuat pot bunga, kotak tempat pensil dan barang lain yang lebih bermanfaat dan bernilai ekonomis. Selain dapat meningkatkan pendapatan masya-rakat, dengan mengolah limbah sabut kelapa diharapkan dapat mengurangi limbah sabut kelapa yang bertambah setiap hari. Berdasarkan latar belakang di atas, maka dilakukan pengabdian kepada masyarakat melalui KKN tematik dengan judul: inovasi teknologi pengolahan limbah sabut kelapa di Desa Sigar Penjalin

Kegiatan pengabdian ini bertujuan untuk membuat pot bunga dari limbah sabut kelapa sehingga dapat menambah nilai ekonomis dari limbah tersebut. Hasil yang diharapkan dari pengabdian kepada masyarakat melalui KKN tematik Universitas Mataram adalah dapat meningkatkan nilai jual limbah sabut kelapa setelah dibuat menjadi pot bunga, dan barang kerajinan lainnya, sehingga dapat meningkatkan pendapatan masyarakat masyarakat setempat.

\section{Metode}

\section{Waktu dan Tempat}

Kegiatan dilakukan selama 3 hari di mulai sejak 30 Juni sampai dengan 2 Juli 2021 di Desa Sigar Penjalin, Kecamatan Tanjung, Kabupaten Lombok Utara.

\section{Alat dan Bahan}

Alat yang digunakan dalam program ini adalah gunting kawat dan penggaris. Sedangkan bahan yang diguna-kan adalah kawat dan limbah sabut kelapa.

\section{Bentuk Kegiatan}

Bentuk kegiatan secara keselu-ruhan dari inovasi teknologi pengolahan limbah sabut kelapa di desa Sigar penjalin terdiri atas: persiapan program, sosialisasai pemanfaatan limbah sabut kelapa, pelatihan pembuatan pot bunga dari sabut kelapa, teknis pemasaran, melakukan monitoring dan evaluasi.

\section{Prosedur kerja pembuatan pot bunga dari limbah sabut kelapa}

Prosedur pembuatan pot bunga dari limbah sabut kelapa terdiri atas:

1. Memotong kawat ram dan membentuk diameter lingkaran dengan ukuran $12 \mathrm{~cm}$, panjang ukuran kerangka luar $48 \mathrm{~cm}$, kerangka lingkaran dalam berukuran $38 \mathrm{~cm}$, dan tinggi pot $18 \mathrm{~cm}$.

2. Setelah pemotongan kawat, dilanjutkan dengan membentuk kerangka bagian dalam pot dengan bentuk lingkaran, begitupun dengan kerangka bagian luar membentuk kerangka lingkaran dengan jarak $1 \mathrm{~cm}$ dan kemudian direkatkan menggunakan gunting.

3. Setelah kerangka pot terbentuk, dilanjutkan dengan memotong kawat ram yang akan digunakan sebagai pot dengan ukuran yang sesuai bentuk pot dan direkatkan.

4. Kerangkan pot yang sudah terbentuk diisi dengan sabut kelapa, mulai dari bagian alas, dilanjutkan mengisi bagian lainnya pada pot.

5. Kerangka pot yang sudah terisi penuh dengan sabut kelapa, pot dirapikan dengan cara mengunting sabut-sabut kelapa yang melewati batas kerangka.

Diagram alir pembuatan pot bunga dari sabut kelapa disajikan pada Gambar 1. 


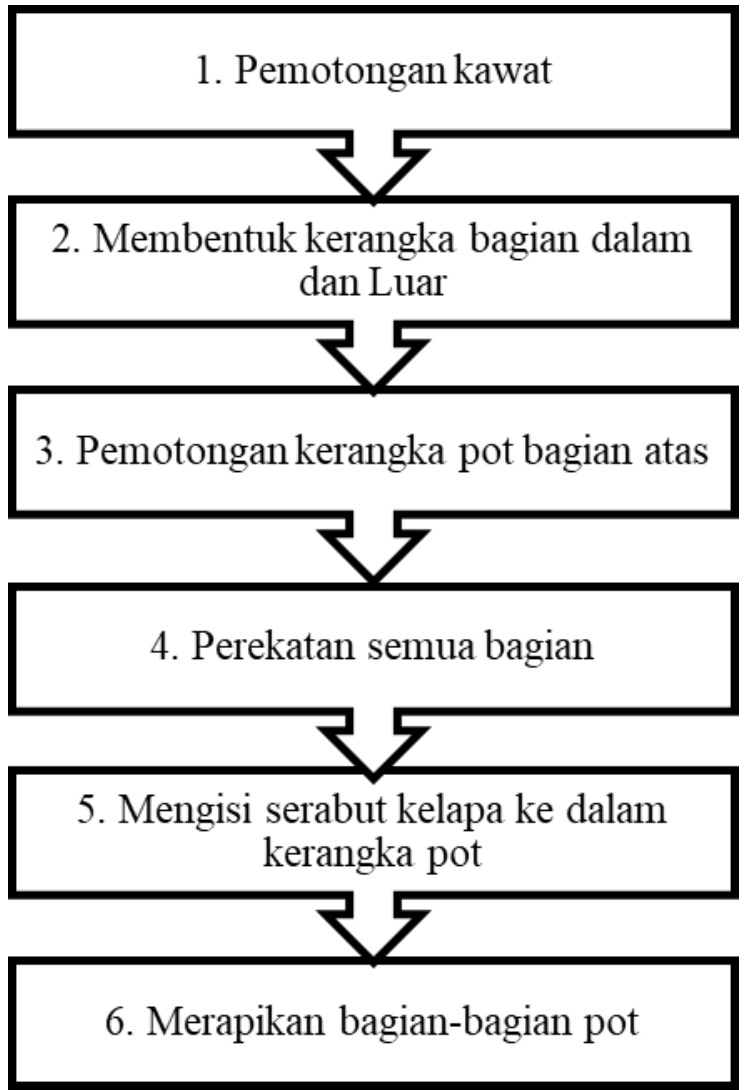

Gambar 1. Diagram alir pembuatan pot Bunga dari limbah sabut kelapa

\section{Hasil dan Pembahasan}

\section{A. Pelaksanaan program pemberda-yaan masyarakat \\ Kegiatan pemberdayaan masya-rakat} dimulai dengan melakukan persiapan program berupa survey lokasi. Dari kegiatan survey yang dilakukan, didapat-kan hasil bahwa terdapat beberapa masalah yang dihadapi oleh masyarakat Desa Sigar Penjalin dalam penanganan limbah sabut kelapa antara lain:

1. Limbah sabut kelapa belum ditangani secara professional.

2. Kurangnya ilmu pengetahuan dan teknologi serta motivasi masyarakat untuk mengolah limbah sabut kelapa

3. Masih minimnya pemasaran produk pengolahan limbah sabut kelapa.

\section{B. Penyuluhan dan pelatihan pembu-atan pot bunga dari limbah sabut kelapa}

Penyuluhan limbah sabut kelapa dan pelatihan pembuatan pot bunga dari limbah sabut kelapa dilakukan di Dusun Cupek, rumah salah satu anggota PKK yaitu Ibu Wahdah. Penyuluhan pertama tentang pemotongan kawat dan pembuatan kerangka dari kawat. Pelatihan ini dihadiri oleh bebrapa anggota PKK Dusun Cupek dengan memerhatikan protokol kesehatan dengan memakai masker, menjaga jarak serta memakai handsanitizer. Penyuluhan dilakukan untuk meningkatkan kreatifitas masyarakat sekitar agar termotivasi dan peka terhadap lingkungan serta dapat memanfaatkan peluang yang ada untuk meningkatkan pendapatan.

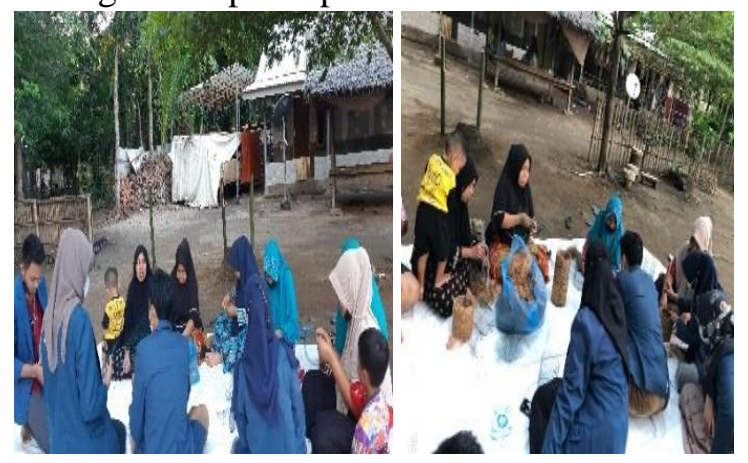

Gambar 2.Penyuluhan pembuatan pot bunga dari sabut kelapa

Kegiatan kedua dari pembuatan pot bunga dari sabut kelapa adalah mela-kukan pelatihan mengenai cara pemisahan limbah sabut kelapa dari serat kasar sehingga sabut kelapa menjadi halus dan dapat dimasukkan ke dalam kerangka dengan mudah. Kegiatan ini masih dilakukan secara manual, yaitu memi-sahkan serat limbah sabut kelapa menggunakan tangan.

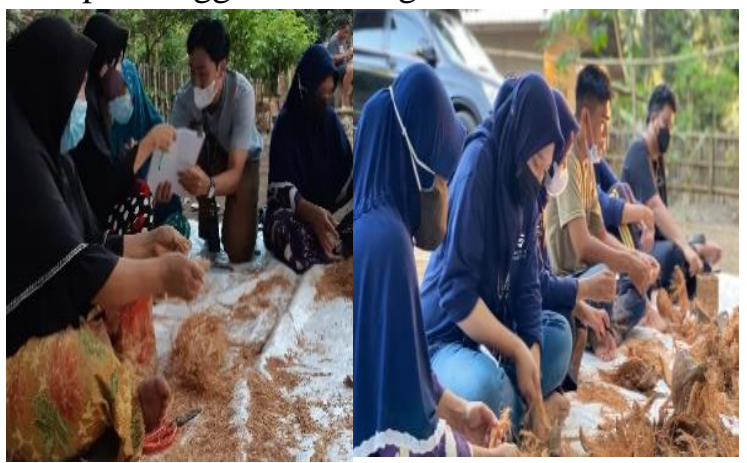

Gambar 3. Pemisahan serat kasar dan serat halus

Kegiatan ketiga dalam pembuatan pot bunga dari sabut kelapa yaitu sabut kelapa dimasukkan ke dalam kerangka menggunakan penggaris agar lebih efisien. 


\section{Monitoring dan Evaluasi}

Hasil monitoring dan evaluasi menunjukkan bahwa masyarakat Desa Sigar Penjalin berkomitmen meman-faatkan dan mengolah limbah sabut kelapa menjadi barang yang bernilai ekonomis seperti pot bunga untuk meningkatkan pendapatan.

\section{Kesimpulan}

Dengan pengolahan limbah sabut kelapa menjadi pot bunga dapat mengurangi pencemaran lingkungan. Pengolahan limbah sabut kelapa menjadi barang yang bernilai ekonomis secara tidak langsung dapat mening-katkan pendapatan ibu-ibu PKK.

\section{Ucapan Terima Kasih}

Dalam pelaksanaan kegiatan KKN ini tidak lepas dari bimbingan berbagai pihak. Melalui kesempatan ini, kami ucapkan terima kasih kepada

1. Ketua LPPM beserta jajaran yang telah memberikan kesempatan kepada para mahasiswa untuk melakukan kegiatan KKN.

2. Kepala Desa Sigar Penjalin yang telah memberikan izin serta menerima kami untuk melaksanakan kegiatan KKN tematik.

\section{Daftar Pustaka}

Amin, Samidi dan K. Prabandono. 2014. Coco preneurship. Yogyakarta: Lily Publisher.

Azzaki, dan A. Dawud. 2020. Potensi pemanfaatan limbah sabut kelapa (Cococfiber) menjadi pot bunga. Jurnal Teknologi Lingkung-an Lahan Basah, Vol.08 No. 1:039-048

Badan Pusat Statistik Kabupaten Lombok Utara. Kabupaten Lombok Utara Dalam Angka 2018. 30 Agustus 2021 